\title{
Narrativas para uma Cidade Floresta
}

Narratives for a Forest City

Anna Julia Dietzsch*, Luis Octavio Pereira Lopes de Faria e Silva**, Paulla Mattos ${ }^{\star * *}$, Sabrina Carvalho Dias ${ }^{\star \star * *}$

*Grupo de Trabalho e Pesquisa "Arquiteturas Tradicionais", Plataforma Arquitetura e Biosfera (Escola da Cidade), Brasil, anna@adietzsch.net

**Grupo de Trabalho e Pesquisa "Arquiteturas Tradicionais", Plataforma Arquitetura e Biosfera (Escola da Cidade), Brasil, lifariaesilva@gmail.com

${ }^{* * \star}$ Grupo de Trabalho e Pesquisa "Arquiteturas Tradicionais", Plataforma Arquitetura e Biosfera (Escola da Cidade), Brasil, mattospaulla@gmail.com

${ }^{* \star \star \star}$ Grupo de Trabalho e Pesquisa "Arquiteturas Tradicionais", Plataforma Arquitetura e Biosfera (Escola da Cidade), Brasil, sabrinacdmontesanti@gmail.com

Palavras-chave:

Depoimentos.

Culturas tradicionais.

Ação regenerativa.

\section{Keywords:}

Interviews.

Traditional cultures.

Regenerative actions.
Resumo

Grupo de Trabalho e Pesquisa (GTP) Arquiteturas Tradicionais (que opera no âmbito da Plataforma Arquitetura e Biosfera, acolhida pela Associação Escola da Cidade), coletados na perspectiva de compreender formas de ressignificar o contato dos povos originários com a Cultura ocidental, valorizando saberes que serão importantes no imprescindível processo de regeneração que urge para o planeta. Defende-se aqui a ideia de uma Cidade Floresta, na qual a ação humana está em harmonia com ciclos naturais, com o ser humano na posição de cultivador e guardião, algo que ecoa e amplifica a maneira tradicional de vida das Culturas indígenas e vai ao encontro da intenção de uma condição regenerativa para a ação antrópica como um todo. Nas entrevistas buscou-se entender a relação dos entrevistados, como representantes de seus povos, com seus territórios e formas de construir, como insumos para a atividade do arquiteto e urbanista. As entrevistas foram transcritas, editadas por participantes do GTP e submetidas aos depoentes para revisões. Também foram objeto de algumas reflexões preliminares, a serem apro-

\section{Abstract}

Article with interviews with Indigenous leaders led by the Traditional Architectures Research Group (GTP), from the Architecture and Biosphere Platform, hosted by Associação Escola da Cidade. In trying to give new meaning/significance to the relationship between Indigenous Peoples and Western Culture, the article highlights the importance of Indigenous knowledge in the much needed process of global environmental regeneration. Based on traditional Indigenous practices, the idea of a Forest City is defended, calling for the reconciliation of natural cycles and human action, and once again placing man in the position of guardian-farmers who can reclaim a regenerative anthropic attitude towards the globe. The interviews sought to understand the relationship of the interviewees, as representatives of their peoples, with their territories and ways of building, as inputs for the activity of the architect and urban planner. The interviews were transcribed, edited by GTP participants and submitted to deponents were also the object of to be expanded in the future.

fundadas oportunamente. 


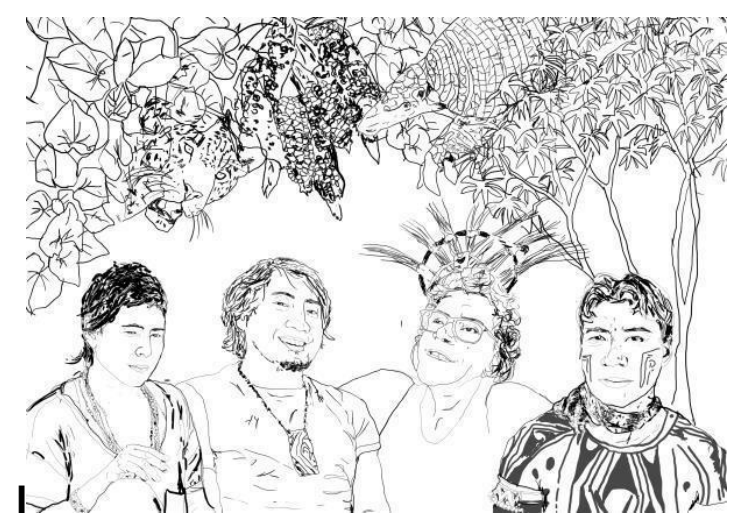

Figura 1 - Lideranças indígenas cujos depoimentos estão aqui apresentados: da esquerda para a direita Jerá Guarani Mbya, Time'i Awaete, Yakuy Tupinambá e Thawá Yudjá, em ilustração de Sabrina Carvalho Dias, a partir de fotografias enviadas pelos depoentes ou realizadas durante conversas com o GTP. Fonte: Acervo do GTP Arquiteturas Tradicionais

\section{Narrativas para uma Cidade Floresta \\ Em busca de outras narrativas}

A ideia deste artigo é a de promover uma escuta entrelaçada de falas de lideranças indígenas com as quais o Grupo de Trabalho e Pesquisa (GTP) Arquiteturas Tradicionais, da Plataforma Arquitetura e Biosfera, tem interagido. Os convites foram feitos para que respostas a questões apresentadas às lideranças fossem devolvidas por escrito, por áudio, ou através de uma conversa que, gravada, pudesse ser transcrita. Todas as lideranças indígenas envolvidas são coautores deste artigo, e o GTP Arquiteturas Tradicionais se coloca como organizador e dinamizador de uma escuta transversal, comparada.

As falas dos depoentes foram transcritas e editadas pelos participantes do GTP e algumas decisões foram tomadas quanto à edição, para que o ritmo proveniente da oralidade original fosse preservado, já que cadência e estruturações da fala deixam entrever uma forma de compreensão específica a ser valorizada, distante de uma sintaxe, por assim dizer, ocidental. Em alguns momentos houve a vontade de deixar

1'projetos como o Manual da Arquitetura Kamayurá - https://www.archdaily.com.br/br/923178/manual-de-arquitetura-kamayura; apoio no redesenho do círculo da aldeia Kamyurá de Ipawu; apoio no projeto da aldeia ritual Janeraka, dos Awaeté, na TI Koatinemo - ver https://ianeraka.org/pt/; es tudos para casa de Reza em Tenondé Porã, aldeia Guarani Mbya em Parelheiros, sul do município trechos como "eles nós somos" (fala de Time'i Awaeté), que mostram uma fusão entre primeira e terceira pessoa. Mas a decisão foi no sentido de não apresentar formas "erradas" de expressão, na medida em que isso poderia passar a ideia de descuido ou mesmo de fragilidade de narrativas feitas em português, na maioria dos casos uma língua não materna para os depoentes. Optou-se, assim, por modificar alguns trechos em nome do respeito e admiração pelas contribuições apresentadas. Nas respostas dos depoentes, nem sempre a ordem das questões se manteve. Preferiu-se deixar livre o convidado para se manifestar.

A inspiração para as perguntas enviadas veio de leituras e da vontade dos participantes do GTP Arquiteturas Tradicionais de melhor entender e divulgar princípios das Culturas com as quais têm tido interações nos últimos anos, que representam oportunidade única de aprendizado.

Duas grandes influências para as entrevistas foram as narrativas de Davi Kopenawa (2010) e de Ailton Krenak (2019) - na perspectiva daqueles que "já viveram o fim do mundo", suas falas chamam para a reflexão sobre três grandes temas, que nortearam nossas perguntas:

1. A não dissociação homem-natureza, que se reflete em todas as manifestações humanas, incluindo a arquitetura em todas as suas escalas

2. O olhar amerindio para a sociedade dos "brancos" ("povo da mercadoria", como Kopenawa se refere), imprescindível na revisão que temos empreendido quanto à maneira de agir e pensar ocidental

3. Possibilidades de ressignificação das relações entre "indígenas" e "brancos".

As questões enviadas, por fim, foram:

1. Como é a relação entre os seres (humanos, animais, plantas, espíritos, antepassados, rios, serras, morros) na sua Cultura? Como começou o mundo para seu povo?

de São Paulo; proposta de Manual de Arquitetura Guarany Mbya a partir da participação em oficina de construção na aldeia Tenoné Porã; projeto para a aldeia Zabelê - Lagoa do Mabaça, dos Tupinambá do sul da Bahia, no âmbito do coletivo Levanta Zabelê ver http://levantazabele.eco.br/; projeto para escola Kuikuru, na Terra Indígena do Xingu - todos em andamento na Plataforma Arquitetura e Biosfera. 
2. Como a aldeia é construída, material e espiritualmente? A configuração da aldeia ajuda na luta pela terra?

3. Como foi o primeiro contato com os brancos para você e para seu povo? O que você pensa sobre o modo que os não indígenas vêem e vivem o mundo e como essas práticas influenciam sua aldeia?

4. Em um ambiente de constante transformação, quais parcerias (sejam com os brancos ou com outros povos) você entende como importantes neste momento? Do ponto de vista de ações propositivas técnicas, há um movimento na sua Cultura de ressignificar a relação com os brancos?

\section{Jerá Guarani Mbya, liderança na aldeia Kalipety ${ }^{2}$, município de São Paulo}

Nhanderu Ete, o nosso pai, criou a primeira Terra e tudo que existe nela. Ficou desencantado com tudo o que estava acontecendo - as pessoas estavam se fazendo mal e não era para ser assim. Então, ele destruiu os seres vivos e o planeta e, um dos filhos dele, Nhanderu Tupã, que também é Nhanderu Tenonde, criou de novo o mundo e tudo que existe nele.

A construção do nosso mundo e da nossa vida é muito complexa - uma das questões é que os corpos aqui neste planeta têm os espíritos, que estão entre o mundo sagrado e esse mundo imperfeito da Terra. E tudo que a gente faz de errado aqui na terra fica impregnado só no corpo físico, o Tekoaxy - o nosso espírito não é prejudicado. Quando a gente morre, nosso espírito volta para a morada sagrada e nosso corpo padece até sumir aqui na própria Terra.

Quando Nhanderu criou o mundo e as pessoas, Ele fez para todo mundo viver em harmonia com a natureza, com os bichos: cada um tinha o seu espaço, porque ele criou um planeta gigante. Assim não faltaria terra ou água para ninguém.

Por isso a gente tem a concepção de viver em paz neste mundo. Achamos muito errado fazer mal um para o outro, tirar a vida do outro, pegar o que não é nosso. Regras de respeito para com a natureza, de pegar só o suficiente, tudo está dentro dos ensinamentos de Nhanderu Ete. Por conta disso, a gente respeita tudo que está à nossa volta. No nosso conhecimento, tudo que está na natureza, neste planeta, tem os seus donos, que chamamos de lja- todos têm vida: por isso que a gente tem que pedir licença quando vai utilizar os recursos naturais.

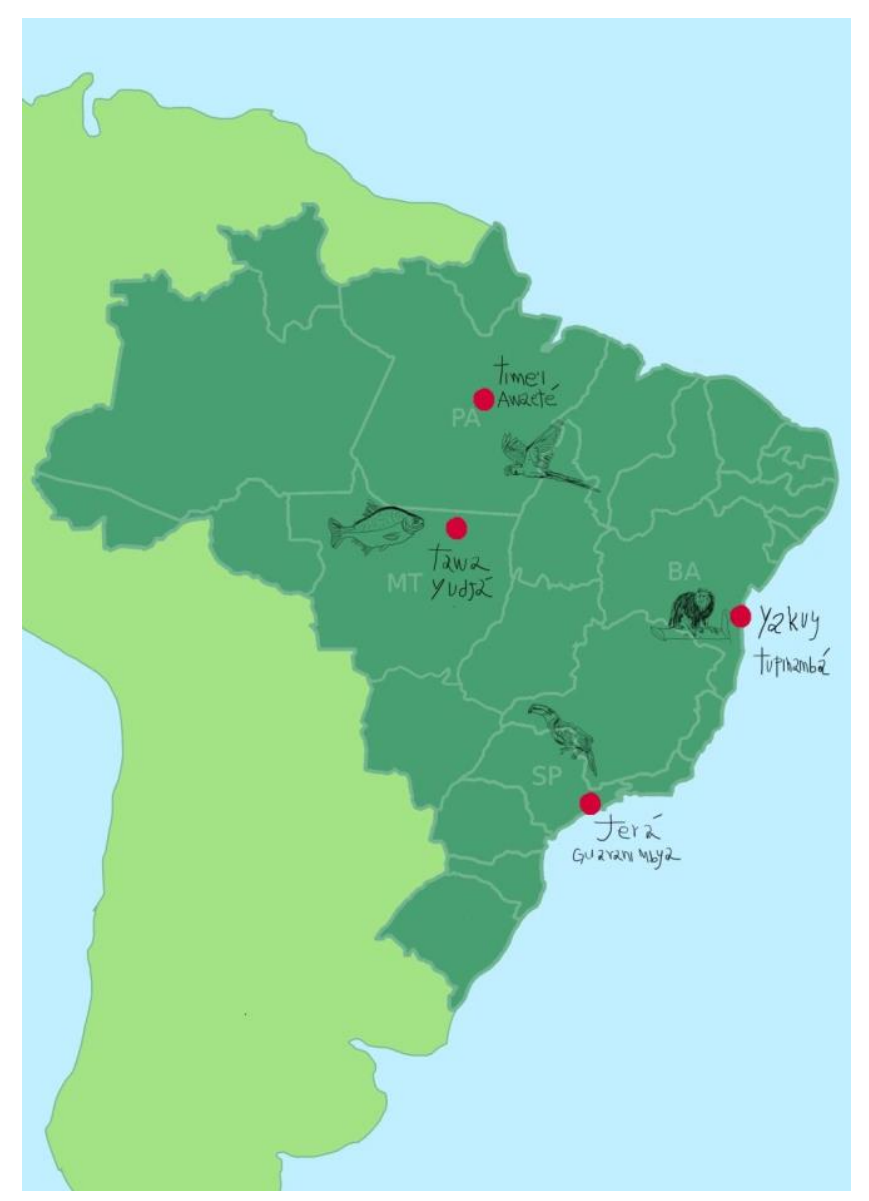

Figura 2. llustração de Sabrina Carvalho Dias com a localização dos Territórios dos entrevistados . Fonte: Acervo do GTP Arquiteturas Tradicionais

Quanto aos nossos antepassados, os espíritos vêm e voltam. Inevitavelmente, nos acostumamos a viver um com o outro, então sentimos saudade, sentimos a dor da

${ }^{2}$ Aldeia Guarani Mbya, em Parelheiros, sul do município de São Paulo, onde vive Jerá. 
perda deste plano aqui, mas no nosso conhecimento os espíritos voltam para a morada sagrada de Nhanderu, que é onde nada perece. Quando alguém morre, a gente vai pra casa de reza, fica a noite inteira cantando e dançando para celebrar que agora o espírito está voltando para Nhanderu. Todas as vezes que vou me comunicar, vou conversar com os Nhanderu, falo também com os Nhe'e Porã, espíritos que já estão na morada sagrada.

Tradicionalmente, os mais velhos tinham, pelos seus sonhos, orientação de onde melhor construir aldeia. Tem os conhecimentos práticos dos mais velhos sobre 0 lugar onde vai se fazer aldeia, se tem matéria prima boa para construir as casas, se tem água perto. Os materiais tradicionalmente usados pelos Guarani eram taquara, bambu e palmeira. As configurações das aldeias, com a luta pela terra, hoje são mais fixas, por conta de não ter mais para onde ir, porque muito do que eram territórios Guarani agora é cidade.

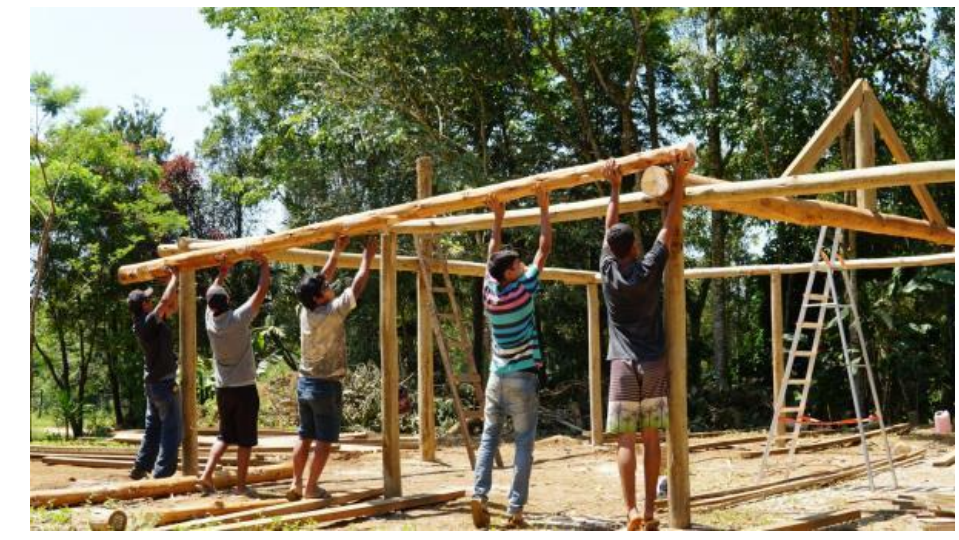

Figura 3. Construção da nova Casa de Reza, no território Tenondé Porã, em 2020. Fonte: Acervo do GTP Arquiteturas Tradicionais

Quanto ao primeiro contato com o povo jurua ${ }^{3}$, uma lembrança forte pra mim foi uma conversa que tive com uma Guarani que tinha umas histórias bem bonitas. Ela contou que o bisavô, o avô e o pai dela sempre falavam que quando os primeiros jurua chegaram no território, de navio, alguns Guarani se enganaram, pensando que eram enviados de Nhanderu para viver com eles aqui na Terra. E foi muito bonito. Aí começou essa coisa de catequizar todo mundo. Quando os Guarani perceberam isso, começaram a fugir. A maioria nunca se enganou - os Guarani sempre souberam que os jesuítas não eram de Nhanderu, pela forma que tratavam, pela forma que falavam. Então, seja pela religião, pela força bruta, pelas armas, cachorros, nosso entendimento do primeiro contato não foi bom, não foi com respeito, não foi com cautela e nem com paz. Sempre foi muito agressivo. Tirando as pessoas de suas aldeias, pegando seus filhos, roubando suas terras.

O modo dos não indígenas viverem, de verem o mundo, influencia a aldeia. Existem muitos estudos de pessoas muito sérias, que dedicaram sua vida inteira para estudar profundamente, apontar tecnicamente, cientificamente, historicamente que o modo de vida de jurua é autodestrutivo e ainda assim, muitos poderosos estão enfeitiçados por essa vida da ganância. Não conseguem enxergar o quanto estão fazendo mal a si mesmos, aos seus semelhantes, e àqueles que não podem levantar a bandeira "queremos viver, fazemos parte da vida de vocês, fazemos parte do equilíbrio para a existência contínua do planeta", como no caso dos bichinhos. Os bichos que são vendidos clandestinamente, as árvores que são cortadas de forma predatória. Ainda que estejamos nesse mundo tecnológico tão avançado, os jurua, principalmente os políticos de todos os países, não se unem de verdade para pensar um novo jeito de fazer as coisas, de plantar, de construir, de confeccionar, de estudar cientificamente como faz, como não faz, sem destruir aquilo que nos mantém nesse planeta. E o Guarani não precisa ir pra escola, fazer mestrado, doutorado, estudar temas voltados para o meio ambiente planetário, para descobrir que a gente não vai conseguir viver sem a natureza, que seus recursos são necessários. Mas os jurua, ainda com muitos estudos, não conseguem ver isso. Toda essa influência da ganância, do valor que se dá para o material, chega na aldeia também via TV, celular, internet. Atualmente, isso tende a bagunçar a vida da aldeia como um todo, começando principalmente pelos jovens. Mas isso não está só no mundo dos jovens, está no mundo dos adultos também. De lideranças, inclusive.

No modo de ser Guarani não existe essa coisa de violência, de estupro, de abandono de filho. Essas coisas erradas vêm pela opressão e violência neste território 
que era indígena. Quando a comunidade fica sem terra, vem o sofrimento, a influência da bebida alcóolica, e quem começa a sofrer mais com isso são as mulheres, os filhos, que vão vendo também essa vida e acabam vivendo tudo isso de novo.

Essa coisa da roupa de marca, andar na moda, pintar o cabelo: tudo isso influencia de forma muito negativa os jovens na aldeia. De várias formas, como com as pessoas que têm salário na aldeia, que se tornam inevitavelmente uma outra classe quando uma família começa a ter coisas diferentes na aldeia: roupa, sapato, que faz aniversário, viagem, dá presente no dia dos pais, no dia das mães, dá presente para os filhos nos aniversários. O que vai causando uma desordem social na aldeia que as pessoas, às vezes, não querem enxergar.

Acho que os jurua, ainda que tenham um conhecimento de fato muito evoluído cientificamente e tecnicamente falando, estão morrendo por conta de mãos humanas, terrivelmente gananciosas e desenfreadas. De pessoas que também têm conhecimento e religião, que teoricamente conseguem ter sentimento, amor para com outras pessoas, sua família, mas que não conseguem multiplicar isso num olhar mais amplo, que é viver neste planeta.

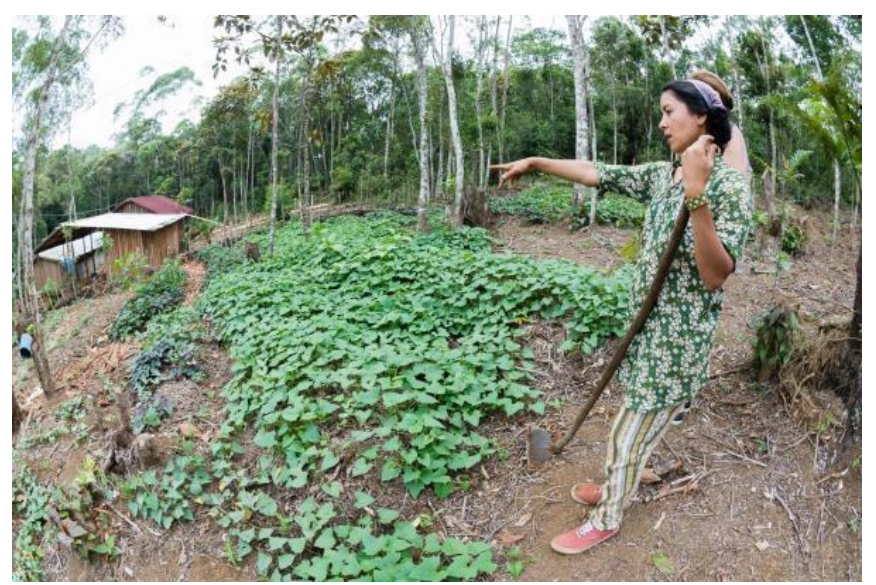

Figura 4. Jerá na roça da Tekoa (aldeia) Kalipety, onde mora. Fonte: Paula Lyn

Há pessoas do povo Guarani, ainda que tenham ido pra escola, que não sabem falar o português, tanto em Parelheiros, quanto no Jaraguá, que está muito próximo da cidade, mas que querem continuar vivendo na aldeia, fumando cachimbo, se esquentando num foguinho no frio. Que querem continuar assim. Aqui na Kalipety, a gente recuperou mais de nove tipos de milho guarani, mais de trinta tipos de batata até o momento. E não precisa desmatar hectares para conseguir toda essa riqueza de novo. Dá pra viver perfeitamente em harmonia com aquilo que nos mantém aqui nesse planeta.

O mundo Guarani também está transformado. Ainda que nos mantenhamos muito Guarani, a gente se depara com muitas coisas diferentes. Como aquilo que a gente come todos os dias, que é a comida que vem de fora, do mercado. Temos escolas, temos internet. Diante de tudo isso, querendo continuar como Guarani, a gente tem, como uma das frentes, a luta pela demarcação. $E$ isso significa que a gente contou e certamente continuaremos contando com os parceiros jurua. Tem muita gente que apoia as lutas indígenas neste país; tem de ter uma parceria maior com esses jurua que tem um coração bom, e que sabem do histórico deste país, que o território brasileiro foi invadido, que aqui tinham muitos povos indígenas, dos quais muitos não tem mais, muitas etnias foram mortas, massacradas, extintas; e que toda essa miscigenação, essa diversidade de pessoas no país, não se fez de forma natural: é uma realidade de um país que sofreu muitos estupros, que as mulheres foram violentadas pelos europeus, sendo manipuladas de várias formas, o que criou esse brasileiro bem misturado. Agora, de fato, tem várias outras situações que se dão de forma tranquila, como eu, por exemplo, estou casada com um jurua e ninguém me obrigou. A gente se achou, se gostou e estamos há dez anos juntos. Mas historicamente, muitas mulheres foram estupradas; mulheres negras, mulheres indígenas.

Acho que este momento é muito importante para nos organizarmos e nos unirmos mesmo. Temos formas diferentes de ressignificar o nosso modo de ser, com tudo que a gente tem, da Cultura de jurua que se torna nossa também. $E$ isso não nos torna jurua. Acho que muita gente está começando a se preocupar com a questão do meio ambiente, do planeta, e que agora a gente tem que unir forças e lutar.

O território fortalece o modo de vida Guarani no seu modelo tradicional, que é onde ninguém faz mal para ninguém, e a gente quer viver desse modo porque não destrói a natureza, e isso significa que teremos mais chances de continuar vivendo e que as gerações vão continuar tendo espaço para viver sua vida. Tudo isso é voltado para a ideia de valorizar a Cultura Guarani Mbya, uma das culturas indígenas como 
todas as outras, que protege a natureza. E o planeta Terra precisa de mais protetores, por isso que eu estou fazendo uma chamada para todos os jurua para se tornarem selvagens.

E como é que os jurua podem se tornar selvagens de imediato?

Saber votar, estudar a questão política, quem são as pessoas, qual a origem; é uma forma de se tornar selvagem. Porque se a civilização está destruindo o planeta e ser selvagem é defender a natureza, a gente tem que se tornar selvagem mesmo.

\section{Time'i Awaeté, Pajé dos Awaeté Assurini do Médio Xingu}

Na convivência dos Awaeté com os seres que habitam e compartilham o mundo ao mesmo tempo, não somos divididos - somos juntos, mas cada um no seu território diferente. A onça, a arara, o papagaio. Somos caça, para eles se alimentarem, mas ao mesmo tempo eles trazem cura. Todo mundo tem medo da onça e ela traz remédio do outro mundo. A gente vive neste mundo, ao mesmo tempo espiritual e onde tudo é vivo. Não tem essa diferença da espiritualidade e convivência com o animal - todo mundo é gente. Todo mundo é irmão. O macaco nos vê como parente. $E$ assim a geração dos Awaeté vem passando. Respeitando o ciclo, junto com antepassado. A nossa casa de reza é feita para guardar a memória antiga, para a gente celebrar e trazer os mortos, porque os mortos não estão mortos, só o corpo deles, mas a alma, o espírito, vive. O corpo humano fica velho, mas quando vê lá no espírito, é forte, saudável, não tem doença. O mundo que a gente vive tem os dois: num deles a gente não envelhece. É assim o mundo que a gente vê: cheio de conexão. Hoje ela está sendo enfraquecida. Isso machuca a floresta, machuca o rio, e nós também, que convivemos com eles.

Por isso gera depressão, porque tira recurso. É a mesma coisa de tirar um nariz teu, perna, uma boca, dente, a língua. Quando mata o rio, corta um pedaço do teu corpo. Teu coração está quase parando. Teu espírito não consegue respirar. A floresta, por si só, fica linda. Nós é que derrubamos, fazemos nossa casa, nossa roça, matamos animal que a gente precisa comer. Ela está ali indefesa, ou até com defesa, porque as doenças hoje que acontecem nas pessoas, ninguém sabe. A água na cidade está poluída, sem floresta. Os indígenas sendo assassinados, os pajés estão indo embora - então, não tem mais proteção - quando acabar isso aí tudinho, a Terra pode explodir - pode acontecer um bocado de coisas e eles que estão segurando, mediando a guerra espiritual. Uma comunidade que não respeita a forma de lidar com o mundo espiritual não evolui, ela enfraquece e gera depressão.

No início mesmo, Mayra criou a mulher e o homem - os animais, não existiam. Nós não sabíamos falar, nós Awaeté viemos numa geração das araras. Temos conexão com araras, papagaio, gavião. Viemos desses seres, dessas aves. Não existia homem, então Mayra pegou o arco, porque não tinha ninguém para conversar, para caçar, para ajudar a fazer roça, plantar, e criou o homem. Ele queria criar povo criou o povo. Então pegou o cajado awoi-yve e o transformou em mulher. E foi criando jabuti, pássaros, castanha. Foi criando esses animais para se comunicar com a gente. E colocando limitações; se fizer isso, vai acontecer tal. Se vocês mexerem assim, vai ficar doente, vai morrer - esse ensinamento que os velhos praticam muito. E deixou também o braço dEle, que é o Pajé, que é a comunicação direta com Ele. Porque o caminho que o Pajé percorre no mundo espiritual, no céu, é o caminho dEle.

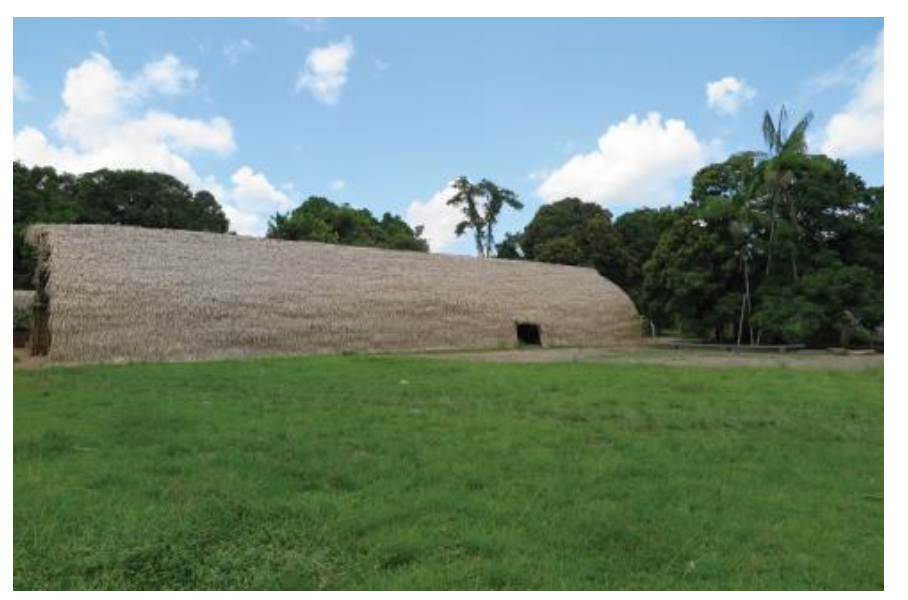

Figura 5. Tawywa (Casa-mãe) Awaeté. Fonte: acervo Instituto Janeraka

Depois vem o Ajaré, o mundo acaba, e a gente surge de novo, através da arara, através da garça. E assim a gente vai se replicando - quando a gente morre, lá no céu, a gente vira garça, vira onça. Nós, humanos aqui, nosso corpo pode acabar, mas os animais nunca vão acabar. Então a gente sempre vai viver. Nós não vamos 
voltar com essa cara de novo, mas com outros pensamentos, mas nós vivemos de novo. Assim que a gente vê a criação: com conexão com os que já foram e com quem está aqui.

Como a gente mexe muito, a gente era muito ligado espiritualmente à terra, onde a gente vai plantar, à casa, às madeiras, às construções. $E$, também, somos muito territorialistas, para marcar território. Como a gente não ficava num lugar só, a gente era em grupo familiar - cada um para um lugar só. Então, para fazer casa, produzir seu artesanato, cantar, praticar canto, depois poder voltar pra aldeia-mãe, a casamãe, Tawywa, para poder compartilhar com os outros, é importante demarcar seu território. Para marcar que nossa família passou por tal lugar, tal mato, tal rio. A gente coloca o nome de cada rio. Tudo isso são águas que nossos avós passaram, onde tinha nossa aldeia, onde aconteceu guerra, então a gente vai marcar o território para ter noção onde a gente está. Porque o Awaeté nunca se perde no caminho. Eles são bons de se localizar. Nunca navegaram muito no rio, mas andavam muito no chão, muito. Então eles precisavam marcar o território para poder se localizar, através do leste, sul, norte - precisava se localizar através das casas e do rio também.

Sempre tivemos que olhar os karaí ${ }^{4}$ escondidos. A gente nunca buscou contato por causa de doença, medo. Mas, cansado de tanta guerra, muitas pessoas mortas, o tio da minha mãe sonhou com karaí que vai ajudar. Ele sonhou, meia noite, quando deu duas horas da madrugada, ele incorporou e falou "Amanhã vai chegar karaí e não vai nos matar, vai conversar e eu vou conversar com ele". E não falava português. Quando deu 8 horas da manhã, chegaram três padres. Aí todo mundo correu. Os padres com espingarda. Aí o velho Pajé pegou o arco e falou "vou correr não".

Aí o padre "vem, vem" - "eu não, vem tu, vem falar comigo tu".

Aí o padre falou "tá com o arco, joga!" - ele falou "não, tu tira e joga o teu. Pega tua arma e joga. Eu vou jogar o meu. Assim a gente vai conversar". Aí o padre tirou o cinturão, colocou no canto. Aí ele pegou o arco dele e jogou. Aí ele foi e abraçou o padre, e o padre segurou ele. Ele avisou para os outros (todo mundo escondido, olhando) - "Olha, ele não vai me matar não, ele está só me pegando. A gente vai entrar em contato e usar a arma dele agora: a cabeça, principalmente a mente". Ele fala que karaí muitas das vezes pensa muito, produz muito, e o conhecimento que ele está produzindo acaba atrapalhando muita coisa bonita. Fazendo hidroelétrica, que mata o rio. Que ele pensa muito, mas o que exatamente ele está produzindo com esse pensamento é negócio. E quando conhecimento desse tipo, de karaí, chega na aldeia, acaba que a gente repete a destruição, acha legal: "vou cortar madeira, vou vender madeira, vou vender peixe, vou vender carne, vou vender ouro". Daqui a pouco, não tem floresta, não tem rio. Nós mesmos estamos nos matando. É a mesma coisa que pegar a faca e se furar todinho.

A gente tem problema na comunidade. Mas não temos pessoas passando fome, nós não deixamos os velhos no asilo. Onde está o conhecimento de karaí de acoIhimento que eles tanto falam? Não acolhe não: abandona o velho. Nós não: velho é sagrado. Aqui é diferente. Isso me deixou curioso, ao mesmo tempo triste, porque eu fui criado com minha avó, até os últimos dias da vida dela. Esse tipo de desvalorização, quando chega na comunidade, cria conflito. E gera depressão. Gera desigualdade, um querer aparecer mais que o outro, e não é assim: é tudo igual.

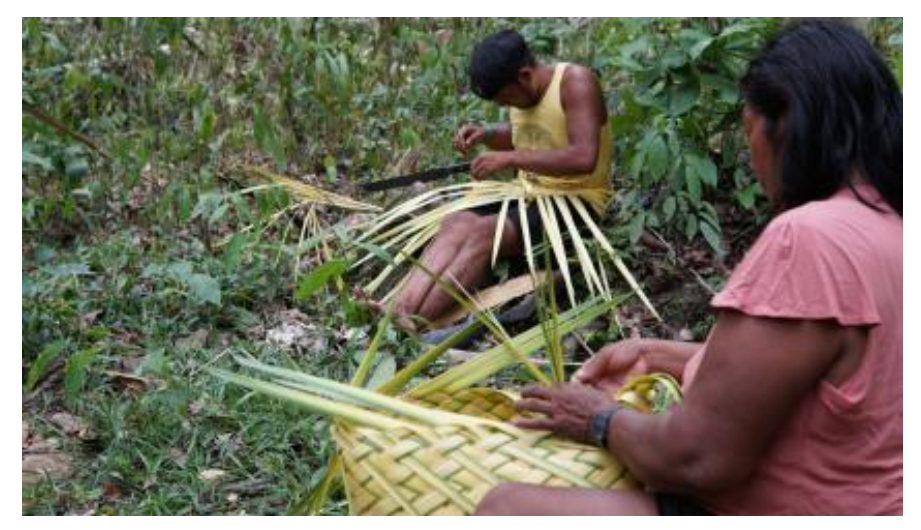

Figura 6. Awaeté trançando palha, fazendo cestos. Fonte: Time'i Awaeté

Eu venho de uma etnia que se chama Awaeté - Awa é pessoa, Eté é verdadeiro. Pessoa verdadeira. Nós somos únicos? Não. Somos guardiões dos nossos conhecimentos, da cantoria, da prática. Quando a gente expande nosso conhecimento, 
quando a gente quer conversar com os outros, entramos numa conexão. Vem problema, vem. Mas nada tira o nosso foco. Hoje, neste mundo de ilusão, muitos também estão se perdendo nesse contato. E muitos dos karaí também sofrem opressão. Eu não tenho que pensar assim "os karaí não prestam". Então, vocês vão falar para mim também: "lá vocês estão tomando cachaça também. Lá vocês estão brigando também, entre vocês. Então vocês também - tudo não presta". Não! A gente sabe que tem o suficiente para se respeitar, se ouvir, dentro das nossas dificuldades, porque eu tenho dificuldade, muitas vezes, de expressar o português, mas ao mesmo tempo, tem um momento que eu pego bacana. Eu explico na maneira legal para a pessoa entender. Quando a gente une nosso conhecimento, seja da floresta, seja digital, o mundo em que a gente está vivendo hoje soma. Quando tem um propósito que seja mais do que dinheiro, o resto acontece.

Neste momento, queremos a paz, queremos mais transparência, harmonia, queremos contar a história real. Tanto para os não indígenas, quanto para nós. Porque muitas coisas foram feitas sobre Cultura, sobre a língua, sobre o xamanismo, mas tudo desrespeitando. Então, neste novo momento, a gente conta a história certa, juntos. A linguagem que a gente fala é muito importante também. Estudando significados, o que está se passando da informação, como a gente convive e quer conviver, de agora para frente. Acho que a gente está nesse momento de refazer. Está mais claro para nós a posição de cada um. Duas cabeças não pensam a mesma coisa que uma. Imagine quatro. Cada um tem um objetivo que pode ser comum. Que pode ser compartilhado, concordado entre si, que vai ser positivo para os quatro, para que possa transcender. Então tudo complementa. Nessa floresta, cada um tem sua importância. A sumaúma não é mais importante do que a bacabeira, nem a castanheira. Cada uma com sua importância. Já pensou se só existisse a bacaba? Não ia dar certo. Então, a gente vê assim, percebe assim, nessa luta, nessa resistência. Nós precisamos, por mais que isso dificulte mais um pouco, a sinceridade. Sinceridade e amor no coração. É assim, nessa nova comunidade, que a gente está disposto a compartilhar nosso conhecimento, e também estamos curiosos para que a gente possa adquirir mais e fortalecer também o outro lado, para todo mundo ficar feliz.

\section{Yakuy Tupinambá, liderança no sul da Bahia}

Pertenço a uma etnia que alguns antropólogos, inclusive o saudoso Darcy Ribeiro, davam como extinta. Ele não tinha a compreensão do que é pertencer a uma raiz que tem todo esse processo histórico.

Nasci em 1960: 460 anos desse processo, desse encontro da forma como se deu. Ainda tive a sorte de escutar uma pessoa que nasceu no século XIX, que me passava coisas que fazem parte hoje da minha formação. Aprendi hábitos da Cultura ocidental e tenho também os da Cultura dos povos originários, que me foram passados pelas pessoas responsáveis pela minha formação familiar.

Para nós, Tupinambás, parte da nossa Cultura já perdemos quando perdemos o tupi, proibido de ser falado na época ainda do Brasil colônia. Quando você perde o idioma já é praticamente $50 \%$ de sua Cultura que você perde. Mesmo assim, a gente resiste e sente essa vontade no nosso âmago de restituir essa memória ancestral.

Eu vivi e nasci no campo, aprendendo essa relação com a natureza, com os animais, com as plantas - essa coisa de você pedir permissão às plantas para tirar um galho ou uma flor, um fruto, esperar a maturação dos frutos, tudo isso eu não aprendi em livro, eu aprendi pela minha avó.

Eu conheci a figura da Caipora, que para nós é a protetora dos animais, dona das matas, e dizia que a gente só deveria caçar o necessário para a alimentação. Eu ainda fui caçadora quando criança, aprendi a fazer arapuca, ia com meu tio para a mata, colocava oferenda nos tocos para a Caipora.

Aprendemos essa relação e não perdemos. Interessantes essas críticas de que no Nordeste não existe mais indígena, por conta desse processo e mistura biológica, mas as pessoas não vivenciaram isso. Eu aprendi desde criança a me esconder se estivéssemos caminhando numa estrada, a colocar o ouvido no chão de longe ouvindo pisadas você se escondia. Esse povo que foi criado desde criança a se esconder não foi extinto. Se houve extinção, foram alguns povos, não a quantidade que os pesquisadores costumam dizer. Aqui, em terras Tupinambá, nós encontramos ainda parentes com um fenótipo forte: nem a mistura biológica conseguiu apagar essa genética. Também não conseguiu o apagamento total da memória ancestral de hábitos, culturas e tradições. Mas perdemos muita coisa, nos afastamos um 
pouco da nossa crença, tem a questão do idioma que faz com que a gente não consiga guardar os nossos segredos, porque a língua que guarda os segredos de um povo.

A gente perdeu também as nossas construções como eram, mas essa relação com os animais, a relação com a fauna e a flora não - nós nos sentimos parte do todo. $A$ mesma importância que eu tenho, todos os animais têm. A gente sabe da importância da existência dessas outras espécies na nossa vida, desse equilíbrio, porque se deixa de existir uma espécie num determinado local, a gente sabe que isso causa desequilíbrio, e sabe disso nessa convivência com a natureza, nessa observação, nesse diálogo.

Sabemos que cada povo tem sua gênese - cada etnia, ou cada grupo, tem sua gênese. Aqui, os mais velhos não nos passaram isso, passaram já com influência da Cultura ocidental e da religião católica apostólica romana.

Olivença tem uma igreja construída com a mão-de-obra escrava indígena pelos jesuítas em 1560-1580: quer dizer, quanto tempo de catequização, quanto tempo de apagamento nós vivenciamos. Então, a nossa gênese se perdeu nesse caminho, mas nós sabemos que outros povos ainda vivenciam isso. E sabemos dos que chamamos de encantados da natureza, temos relação com eles como divindades - temos a relação com o sol como divindade, com a lua como divindade, o vento como divindade, então de alguma forma não perdemos tanto. Temos essa relação com o que nos dá vida: com o fogo, com a água, com a terra, com o ar, que são divindades - é nesse sentido que a gente se relaciona.

A gente pensou em ir construindo esse movimento de formar, encontrar pessoas,

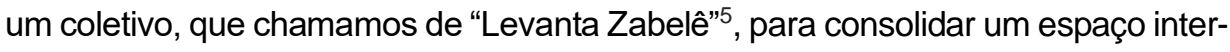
cultural dos saberes, uma escola filosófica que a gente está tentando montar aqui no território Tupinambá. Uma escola filosófica dos povos originários, para trocar saberes com todas as outras Culturas, diferente da imposição que a Cultura ocidental faz quando chega aqui, que nega todas as outras Culturas existentes e cria estratégias de apagamento.

${ }^{5} \mathrm{O}$ Coletivo Levanta Zabelê é formado por uma rede de apoiadores de variadas origens, culturas e áreas do conhecimento, para realização do projeto do espaço do Universo Autônomo Intercultural dos Saberes Útero Amotara Zabelê (UAISZ), que consiste em uma escola filosófica dos povos
Em um momento da minha vida, pensei que minha cabeça era um mundo à parte eu tinha dificuldade de estabelecer um diálogo mais aprofundado. Mas quando eu comecei a ter mais força nas pernas e a sair, fui encontrando pessoas que estão na mesma frequência que a minha - dá para a gente sentar e conversar. Hoje sei que não estou sozinha, nem maluca. Porque eu ouvia muito "você é doida, você é maluca" e não me davam ouvidos - "tá falando bobagem", e isso faz você se calar, eu não tinha liberdade de expor o que pensava e a forma como eu enxergo o mundo. Mas fui encontrando pessoas e, nesses encontros, a partir da escuta, descobrindo como se constroem os pensamentos, que são levados para a ação - o que faz você ser, pensar, agir.

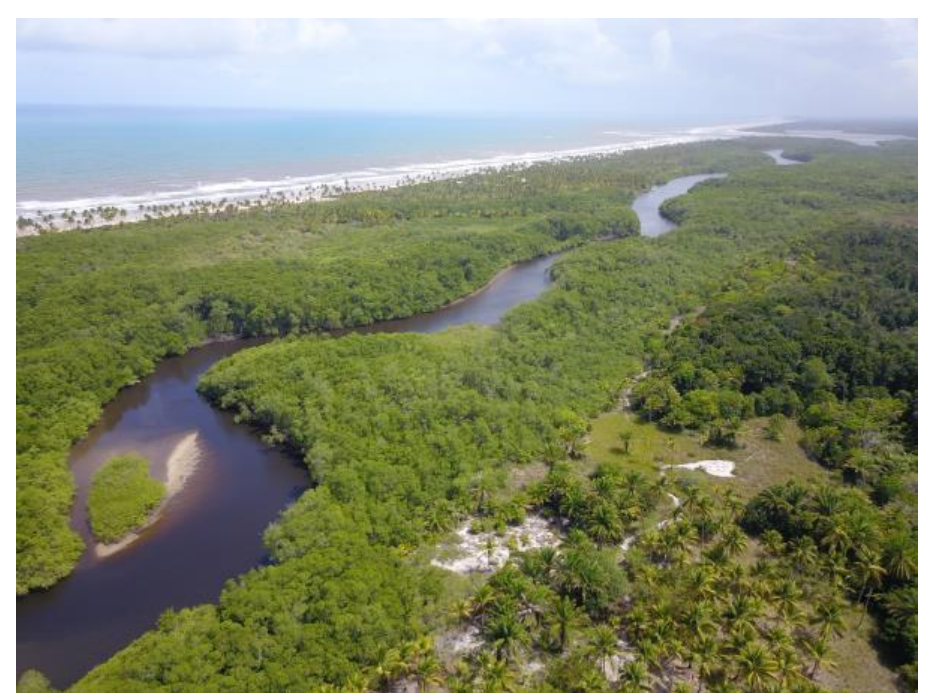

Figura 7. Foto de parte do território Tupinambá no Sul da Bahia, onde numa clareira, à direita, vêse o Círculo Sagrado dos Quatro Elementos, onde será edificado o Útero Amotara Zabelê (escola de Filosofia dos Povos Originários). Fonte: Coletivo Levanta Zabelê.

O período que eu passei na faculdade me ajudou muito, ainda mais no curso de Direito, com muita História. Deu para ampliar muito esse conhecimento. Daí veio

originários, idealizada por Yakuy Tupinambá, cuja primeira sede será no Território Tupinambá em Una-BA. 
surgindo essa ideia da formação do espaço intercultural dos saberes. Eu penso que essa escola filosófica é o óbvio: ela está aí - é só fazer acontecer, é algo que pode se movimentar, que pode fortalecer e motivar a espécie humana a buscar um equilíbrio!

Em todas as relações, surge uma compreensão de que precisamos escutar - daí veio a ideia: é preciso reunir pessoas para essa escuta, para trocar saberes, e precisa de um espaço. E aí, pensando nisso, também de termos, aqui no território, uma réplica das moradias dos nosso antepassados: o quanto isso vai fortalecer o nosso povo na hora que chegar dentro de uma maloca dessa e a gente falar "isso aqui é uma maloca que, segundo os historiadores, no nosso povo se conseguia viver em 100 pessoas, e dentro de uma maloca dessa é que eles lutavam pela vida, e hoje a gente pode ter isso aqui, e nossas futuras gerações podem passar por isso".

Foi um problema no início quando nos reunimos com vários arquitetos que não conhecem a realidade aqui. Daí a importância das casas em círculo, com espaços entre elas voltados para os pontos cardeais de modo a permitir a entrada e circulação dos ventos - um desenho que para a gente é uma arquitetura sagrada. O que o arquiteto vai fazer é colocar elementos de outras Culturas porque as diferenças se complementam - é nesse sentido que a gente vem trazendo a importância para os povos originários de ter essa construção respeitando a nossa ancestralidade, porque isso é o alicerce que sustenta. A importância desse alicerce que é fortalecimento cultural, e daí a gente trabalhar outras coisas: a restituição da autonomia que nós perdemos, a união, se bem que sabemos que historicamente havia conflitos hoje a gente tem noção que esses conflitos podem deixar de existir se as pessoas estiverem mais abertas, se tiverem essa compreensão de que o diferente complementa e não divide.

É importante que a gente traga essa troca de saberes com outras culturas, principalmente com a Cultura ocidental, que tem coisas interessantes, tem coisas muito boas.

Interessante, em se tratando desse útero maior que a Mãe Terra é, que a espécie humana vá nessa busca de ter a compreensão do todo. Daí a Cultura dos povos originários ser interessante - da relação que a gente têm desse todo, porque temos essa relação com os animais, de olhar para o animal e sentir como se fosse um de nós, que tem que ser tratado com respeito, que tem que deixar eles viverem como nós também queremos viver; a ciência hoje diz que as plantas se comunicam pelas raízes, e não deve ser somente pelas raízes. Acredito que essas relações devem ser trabalhadas, lapidadas.

Importante a Academia se aproximar dos povos indígenas e ter abertura porque, até hoje, chegam para suas pesquisas, suas teses, coletam dados e fazem mestrados e doutorados, seja lá o que for, e a gente nem sabe depois para o que aquilo é utilizado. Não há, assim, um reconhecimento. Importante para nós, povos originários, que haja essa relação de respeito, compreensão de que todos participam. Quando você logra a condição de ser útil, tanto você pessoalmente ganha força para continuar fazendo e se melhorando, como você coloca no mundo coisas interessantes, que ajudam, mas quando há essa coisa de um se sobrepor ao outro, a ponto de negar a existência do outro, isso é morte, é genocídio.

Eu nasci no município de Buerarema - tem llhéus, Itabuna, Buerarema, Una - tudo próximo. Mas eles tinham uma relação com Olivença, onde os mais velhos nasceram. Todas as festas que tinham em Olivença eram ligadas à religião católica - todas essas festas eu era trazida para participar. E não tinha acontecido essa coisa do turismo. Era a maioria indígenas mesmo - poucos não indígenas em Olivença nessa época. As casinhas ainda eram de taipa, muitas cobertas de palha.

Mesmo nas décadas de 60-70, não se preocupava em fazer uma casa que durasse muito tempo - iam saindo aqueles torrões e ficando esburacada e eles nem se importavam em fazer a manutenção: às vezes preferia fazer outra casa em outro lugar. $\mathrm{Na}$ construção do indígena, a casa é para passar pouco tempo, era casa na beira da praia, nos barrancos. Só tinha preocupação que a enchente não penetrasse nas moradas - era mais próximo do rio, do mar, por causa da pesca e no local onde tivesse caça também. Nessas construções era "vamos montar o acampamento aqui porque tem caça e pesca".

Meu companheiro nasceu aqui em 1963. Ele ficava aqui um tempo, depois não queria mais ficar e ia para um lugar próximo - então, essa relação para nós, povos originários, não é a mesma que a Cultura ocidental tem. Território para a gente é o local onde você vive, onde você pode viver, e não tem "isso aqui é meu, é minha propriedade e aqui eu vou me estabelecer e pronto". Essas condições que nos foram dadas impedem parte da nossa Cultura e hoje nós somos obrigados a ser sedentários. 
Em 2002, houve o reconhecimento oficial do povo Tupinambá de Olivença. Aqui já houve alguma demarcação na época da Coroa - era Marquês de Pombal ainda uma medida que onde houvesse aldeamento jesuíta era para demarcar 7 léguas quadradas. Muito mais do que a área que a gente está pleiteando agora, que são 47.000 hectares. Na época da Coroa eles botaram os marcos de bronze - na implantação da lavoura cacaueira, os fazendeiros retiraram esses marcos e também $\mathrm{ACM}^{6}$ deu muitos títulos de terra nessa área, que já estava delimitada pela Coroa portuguesa e que, com a grilagem, ficou pequena. Nesses 47.000 hectares, nos municípios de llhéus, Una e Buerarema, são 23 comunidades. Depois de estudo antropológico, aconteceram algumas retomadas. Tem áreas de retomada e territórios ocupados tradicionalmente, nunca vendidos, da União.

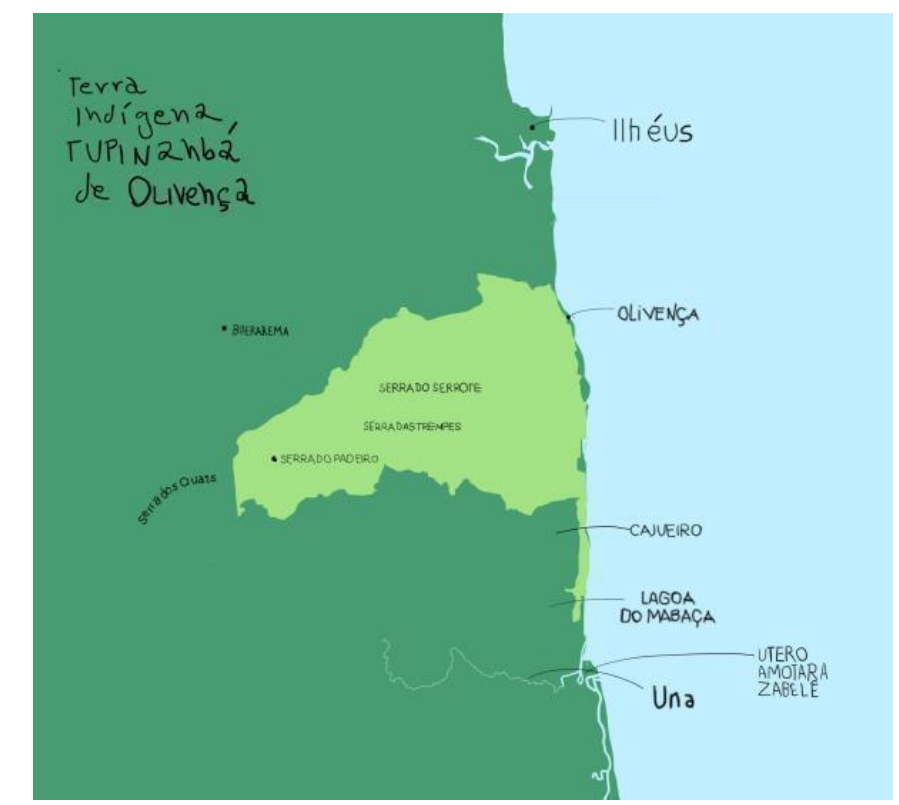

Figura 8. Ilustração produzida por Sabrina Carvalho Dias com referências presentes na fala de Yacuy. Fonte: Acervo do GTP Arquiteturas Tradicionais

${ }^{6}$ Acrônimo de Antonio Carlos Magalhães, político influente na Bahia durante a segunda metade do século XX.
Estamos na luta por esse território que não abandonamos. Quando aconteceu o aldeamento jesuíta e de lá pra cá, os povos continuaram transitando por aí. Também tiveram que enfrentar vários processos: êxodo rural e as violências que foram sofrendo.

\section{Thawá Yudjá, realizador de agroflorestas no alto Xingu}

O mundo, dentro da nossa Cultura, já existia com a sua própria visão, o seu próprio espírito, seu próprio coração, sua própria mente. Antes, bem antes de o ser humano existir na terra, existia uma obra do Criador. Espécies de plantas, variedade de animais, que o Criador trouxe espiritualmente e que botou a nascer dentro da Terra. Os tempos vão passando e todas essas obras dele aconteceram, foram desenhadas, e foram os primeiros seres humanos que existiram, antes do verdadeiro ser humano. Existiam diversas plantas, plantas de poderes, as montanhas, os rios, córregos, morros, ventos, o ar: então, esse relacionamento entre todos, essa união foi um dos momentos do tempo em que todas essas, vamos dizer assim, variedades de gente que existiram primeiro, que foram colocadas na Terra, foram como se fosse hoje a gente existindo. Esse era o nosso desenho. Quando chega no tempo certo, mudanças, transformações, e esses, que vieram como gente, se transformam com seus próprios espíritos, como as várias espécies de plantas, os tipos de vegetação, montanha, os morros. Para nós, todos têm seus espíritos por causa disso. Assim o mundo surgiu para nós. Sabemos como cada planta, cada coisa tem seu próprio dono, seu próprio espírito, que surgiu para dar esse primeiro passo para surgir a humanidade. Somos a segunda humanidade que surgiu. Para o povo Yudjá, nesse relacionamento entre plantas, animais, espíritos, rios, serras, morros, tudo tem espíritos e sua comunicação forte. Nós sabemos lidar com todos esses espíritos.

Sobre como nossas aldeias são construídas materialmente, construímos uma aldeia sempre escolhida pelos anciões. A gente tem mudado muito as aldeias por andar muito - o povo gosta de andar muito longe. Assim construímos as nossas casas - casas tradicionais. Hoje em dia, nossa aldeia continua se mantendo da forma como se fazia antigamente: o formato da aldeia, sempre redonda. Assim 
construímos a nossa aldeia, as nossas casas. Isso, para a gente, tem força dos antepassados. A gente continua vivendo com a energia dos nossos ancestrais, conforme a gente usa o modelo dos nossos ancestrais. Isso nos leva sempre firmes.

Hoje, lutamos para continuar preservando nosso território, nossas florestas, nossos rios, nossa caça, nossos peixes, nossos alimentos da roça, cuidando das sementes da roça, das sementes nativas da floresta, plantando. Isso nos fortalece para continuar cuidando da nossa terra. E lutando pela terra. Isso que nós temos no coração e na mente, para levar a luta sempre firme e com as energias positivas, construindo um futuro melhor.

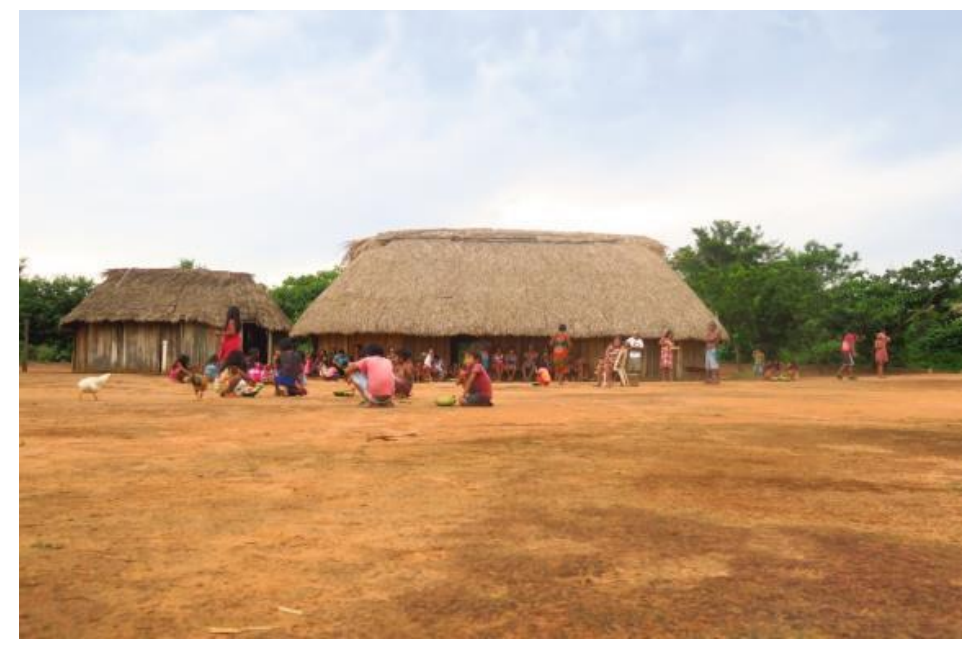

Figura 9. Cotidiano na Aldeia Yudjá (ao fundo, Casa Tradicional). Fonte: Clarissa Morgenroth.

O primeiro contato dos não indígenas com os Yudjá começou séculos atrás, em alguma região da Amazônia. Conforme os tempos foram passando, começou a ter conflito do povo Yudjá com os não indígenas - os brancos. Assim o povo Yudjá foi construindo os seus caminhos para ser livre de conflitos: começou a ir mato adentro e subir o rio. O contato começou com a chegada deles - os brancos - foi bom no início, mas tempos depois começaram conflitos. Num primeiro contato, vamos dizer, a sujeira vem junto. Começaram conflitos e começaram a se espalhar. Depois, os
Yudjá chegaram no Pará - antes não existia essa divisão - era tudo floresta em todo canto. Chegou onde hoje existe uma cidade chamada Altamira - lá juntou o povo Yudjá, fizeram nesses tempos a aldeia e aí chegaram outros invasores. Também na chegada foi bom, e no passar dos tempos também começaram a pressionar, tiveram muitas coisas ruins. Então, o povo começou também a se dividir e uma parte veio para o Mato Grosso. Hoje estamos aqui no Mato Grosso e tivemos muito conflito com não indígena, principalmente os seringalistas. Último e terceiro contato tivemos aqui no Mato Grosso, no Xingu - já fazia muito tempo que o povo morava aqui. Anos depois, os irmãos Vilas Bôas chegaram aqui no Xingu e tiveram também contato com o povo Yudjá. Assim é a história do contato do povo Yudjá com os não indígenas. Hoje, a gente enxerga, tem esse olhar amplo no mundo e, de olhar para a sociedade não indígena e esses seus pensamentos, olhar diferente, focos diferentes, as vivências diferentes e muito mais que eles querem destruir. Isso tenta também influenciar as aldeias. Mas pelo que eu entendo e que meu povo entende, sobre como o homem branco vive o mundo: é totalmente diferente do que o povo Yudjá tem, seus pensamentos com o mundo, seus olhares para o mundo - existe um jeito melhor para o povo Yudjá de aprender e descobrir e de construir as coisas para o mundo - não só destruir, mas usar de forma correta as coisas que o mundo oferece para a gente. Tudo isso está sendo desassistido na sociedade branca - isso a gente enxerga aqui no Território Indígena do Xingu. Isso que o povo Yudjá enxerga para tentar trazer esses ensinamentos profundos que vêm de coração, da mente e dos seus sentimentos para o mundo.

Aqui dentro do nosso território, a gente tem esse convívio de cuidar, de preservar a nossa floresta, tem o nosso costume, nossas tradições, de continuar levando a nossa Cultura viva. Tivemos conflitos com as madeireiras, com invasão de pesca predatória - e até hoje nós também estamos de olho nos limites do nosso território para que a gente continue esse cuidado, por que tudo o que você fizer hoje, nós estamos no Brasil, com Culturas diferenciadas, tanto dos indígenas e não indígenas. Muitas das vezes, a gente tem encontrado essa situação que vem agredir, trazer situação complicada do lado da gente. Isso nos traz essa preocupação muito grande e continuamos levando com esse cuidado, esse foco - esse jeito de proteger nosso território. Temos essa luta. Também existem nossos parceiros não indígenas que são pessoas que têm feito um trabalho muito bom - essas pessoas trabalham com seus sentimentos. Muitas das vezes, isso fortaleceu o nosso trabalho. Na verdade, 
a gente conta, procura todos os parceiros que estão fazendo parte da nossa história, que fazem parte da construção desse caminho para todos.

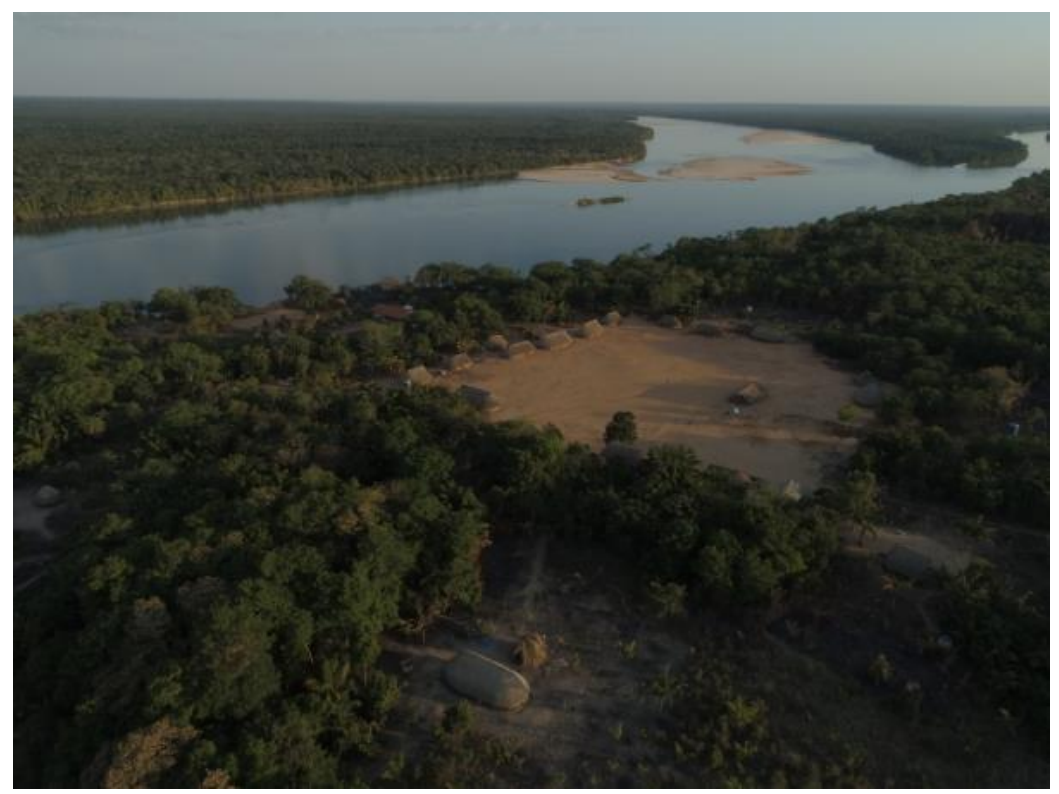

Figura 10. Aldeia Yudjá de Tuba-Tuba, no Território Indígena do Xingu. Fonte: Kamikia.

O que realmente a gente quer é respeito na humanidade. O mais importante para a gente é continuar vivendo e respeitando um ao outro. Não importa se é o branco, 0 indígena, negro, de outros países - o que importa para nós é que todos estejam conscientes de comos queremos construir nossos futuros. O que o mundo diz sobre a vida para nós. Tudo isso nós temos que descobrir e deixar crescer esse sentimento em relação à natureza. Porque nós, seres humanos, somos filhos da natureza. Muitas vezes a própria humanidade tem desrespeito com a nossa mãe natureza. Sempre lutamos junto com nossos parceiros, parceiras, com outras

${ }^{7}$ para o conceito de Cidade-Floresta, ver:

DIETZSCH, Anna "For the design of an Amazon Forest City - part 01" disponível em: https://www.thenatureofcities.com/2020/06/11/third-landscape-part-1-for-the-design-of-an-amazonforest-city/ instituições, com outros parentes, com outros irmãos não indígenas que estão na luta - isso faz o bem para todos. Tanto para nós humanos como para o mundo, para a natureza, para o universo. E para nosso ar, nosso modo de vida. Para o jeito de viver. Isso que o povo Yudjá pensa sobre a parceria e a relação com todos.

\section{Insumos para uma outra condição - caminhos para uma Cidade-Floresta ${ }^{7}$ ?}

Algumas perguntas mobilizam os participantes do GTP desde o início de suas atividades e estiveram presentes em todo o processo do qual resulta o artigo aqui apresentado: $\mathrm{O}$ que podemos aprender com os povos originários e como, com eles, podemos co-criar uma forma de nos relacionarmos com o planeta em que os vários saberes estejam entrelaçados? Qual o papel do arquiteto com formação ocidental diante da Cultura dos povos originários, cujas demandas e saberes têm tanto a ensinar na situação da crise socioambiental que enfrentamos?

O caminho em construção, alimentado por essas indagações, é o de uma Cidade Floresta, ideia que defende uma urbanidade alternativa, com a transformação de nossas cidades para que deixem de ser plataformas de esgotamento daquilo que chamamos de "natural", para se tornarem fortes aliadas à sua existência. O conceito estruturador é simples: "(re)construir a natureza ao (re)construir cidades. O que isso implica, no entanto, é a mudança de paradigmas enraizados como valores universais ou imutáveis, que no contexto da crise climática se mostram como empecilhos ao desenvolvimento no longo prazo" (DIETZSCH, 2021). Alguns desses princípios se percebem expressos nas falas aqui compiladas, em que se identificam formas de lidar com a existência e com o meio que vão ao encontro das necessidades prementes: compreensão da conexão entre todos os seres para garantir equilíbrio no sistema, cuidado com os ciclos naturais, solidariedade e compartilhamento respeitoso dos saberes e do conceito comunitário.

Há, nesse sentido, uma perspectiva que perpassa as falas dos depoentes de que neste planeta o ser humano é parte de um conjunto: segundo Jerá, "têm os espíritos também, que estão entre o mundo sagrado e esse mundo imperfeito da Terra", e

DIETZSCH,Anna; MORGENROTH, Clarissa. "For a Forest City" (video) disponível em https://youtu.be/ldL5ubtZtug 
diz que com eles e com os antepassados ela se comunica. Time'i fala dos "seres que habitam e compartilham o mundo ao mesmo tempo" e que "não somos divididos - somos juntos, mas cada um no seu território diferente". Yakuy trata dos "encantados da natureza", e ao falar de si e do povo Tupinambá, diz: "temos relação com eles como divindades - temos a relação com o sol como divindade, com a lua como divindade, o vento como divindade". Para os Yudjá, segundo Thawá, "todos têm seus espíritos": humanos, animais, plantas, morros, rios. Na medida em que todas as formas de existência - seres e elementos, - são entendidos como parte de um todo, é imprescindível o respeito a qualquer um deles e à Terra como um conjunto vivo.

Essa maneira de compreender é fundamental na revisão que o pensamento ocidental precisa empreender, condição básica para frear o movimento suicida de destruição que vemos em curso. A ideia trazida por Jerá de que "todos têm vida: por isso que a gente tem que pedir licença quando vai utilizar os recursos naturais", e portanto, de que há "regras de respeito para com a natureza, de pegar só o suficiente" é fundamental neste momento, algo que também está presente na fala de Yakuy que relata "essa coisa de você pedir permissão às plantas para tirar um galho ou uma flor, um fruto, esperar a maturação dos frutos" como algo inerente à sua Cultura. Importante lembrar que essa perspectiva de relação entre os seres está presente tanto nos depoimentos a partir de etnias que vivem em regiões onde as condições naturais são mais presentes, como naquelas que estão em regiões urbanizadas em maior ou menor medida, todas sob pressão do avanço de uma dinâmica dita modernizadora que desestrutura a vida da aldeia.

Quanto à construção do lugar coletivo, dimensão espacial da comunidade, Jerá nos conta que "tradicionalmente, os mais velhos tinham, pelos seus sonhos, orientação de onde melhor construir aldeia". Yakuy, por sua vez, diz que o princípio tradicional das construções Tupinambá é "montar o acampamento aqui porque tem caça e pesca" e o território é "o local onde você vive, onde você pode viver", o que desvela uma relação com o meio em outra chave, mais sutil. E, para os Yudjá, segundo Thawá, a "aldeia continua se mantendo da forma como se fazia antigamente", e diz "assim construímos a nossa aldeia, as nossas casas. Isso, para a gente, tem uma força dos antepassados". Percebe-se assim uma outra conexão com o lugar onde se habita, muito distinta da visão mercadológica com a qual nos aproximamos dos nossos territórios. Aqui, a "urbanidade" parte de um entendimento íntimo não só daquilo que é a estrutura natural do lugar, mas também daquilo que foi passado como herança cultural e identitária.

As falas dos depoentes apontam para a possibilidade de outra forma de relação entre os seres. Time'i lembra, nesse sentido, de que "uma comunidade que não respeita a forma de lidar com o mundo espiritual não evolui, ela enfraquece e gera depressão". Segundo ele, "somos guardiões dos nossos conhecimentos, da cantoria, da prática" e podemos pensar em uma "nova comunidade" - referindo-se aos Awaeté, diz: "a gente está disposto a compartilhar nosso conhecimento, e também estamos curiosos para que a gente possa adquirir mais e poder fortalecer também o outro lado, para todo mundo ficar feliz". Generoso convite para que os saberes sejam compartilhados em nome de um crescimento comum. Yakuy, nessa trilha, reflete sobre a perspectiva de um encontro reinventado: "É importante que a gente traga essa troca de saberes com outras culturas, principalmente com a Cultura ocidental, que tem coisas interessantes, tem coisas muito boas", na medida em que é "interessante, em se tratando desse útero maior que a Mãe Terra é, que a espécie humana vá nessa busca de ter a compreensão desse todo". Encerramos adicionando ao convite de Yakuy também o nosso, para que juntos possamos pensar e criar uma outra forma de construir. Não só nossas cidades, mas também nossas relações com elas.

\section{Referências}

DIETZSCH, Anna. Cidade Floresta no Xingu. Revista SeLect, Vol. 10, N. 51, 2021 KOPENAWA, Davi; ALBERT, Bruce. A queda do céu: palavras de um xamã yanomami. São Paulo: Companhia das Letras, 2010.

KRENAK, Ailton. Ideias para adiar o fim do mundo. São Paulo: Companhia das Letras, 2019. 